\title{
The long-term effects of plasma disc coagulation therapy for cervical disc hernia
}

\author{
Servikal disk hernisinde plazma disk koagülasyon tedavisinin uzun dönem etkileri
}

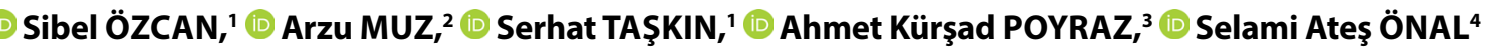

\begin{abstract}
Summary
Objectives: Recently, plasma disc coagulation therapy (PDCT) has been used in the treatment of lumbar and cervical disc hernia $(C D H)$, but the long-term effects of PDCT have not been well documented. The aim of this study was to assess the longterm effects of PDCT on pain score, disc volume, and patient satisfaction in patients with CDH.

Methods: Eighty patients with $\mathrm{CDH}$, who underwent PDCT treatment, were included in the study. The patients demographics and pain scores [visual analog scale (VAS)] were recorded on the baseline and in the $1^{\text {st }}, 3^{\text {rd }}, 6^{\text {th }}$, and $12^{\text {th }}$ months after PDCT treatment. We evaluated patient satisfaction and disc volume on the $12^{\text {th }}$ month after PDCT.

Results: A statistically significant and time-dependent decrease was determined in VAS score. The initial mean VAS score was $6.5 \pm 0.9$, and it decreased to $3.4 \pm 0.2$ on the final follow-up $(p<0.01)$. According to magnetic resonance imaging pathology, VAS score after PDCT was higher in patients with an extruded disc when compared to patients with bulging and protruded discs at all times $(p<0.05)$. After 12 months, $50 \%$ of the patients were reported as excellent and $8.7 \%$ of the patients reported as poor based on the Odom criteria. Disc volume decreased after PDCT treatment in the patients who reported that they were excellent based on the Odom criteria $(p<0.01)$.
\end{abstract}

Conclusion: This study demonstrated that PDCT is a safe, effective, and minimally invasive treatment technique for adequately selected patients with $\mathrm{CDH}$.

Keywords: Cervical disc hernia; disc volume; plasma laser therapy; visual analog scale.

\section{Öz}

Amaç: Son zamanlarda, lomber ve servikal disk hernisi (SDH) tedavisinde plazma disk koagülasyon tedavisi (PDCT) kullanılmıştır, ancak PDCT' nin uzun dönem etkileri tam olarak belgelenmemiştir. Bu çalışmanın amacı, servikal disk hernili hastalarda PDCT' nin ağrı skoru, disk hacmi ve hasta memnuniyeti üzerindeki uzun dönem etkilerini değerlendirmektir.

Gereç ve Yöntem: PDCT tedavisi uygulanan 80 SDH hastası çalışmaya alındı. Hastaların demografik özellikleri ve ağrı skorları (görsel analog skala-VAS) başlangıçta ve PDCT tedavisinden sonraki 1., 3., 6. ve 12. aylarda kaydedildi. PDCT'den sonraki 12. ayda hasta memnuniyeti ve disk hacmi değerlendirildi.

Bulgular: VAS skorunda zaman bağımlı ve istatistiksel olarak anlamlı azalma saptandı. Başlangıçtaki VAS skoru $6.5 \pm 0.9$ iken, son takipte $3.4 \pm 0.2$ olarak tespit edildi $(p<0.01)$. Manyetik rezonans görüntüleme patolojisine göre, PDCT sonrası VAS skoru ekstrüde diski olan hastalarda, bulging ve protrüzyon olan hastalara göre daha yüksekti $(p<0.05)$. Tedaviden 12 ay sonra Odom kriterlerine göre hastaların \%50'si mükemmel olduğunu bildirirken, \%8,7'si kötü olduğunu rapor etti. PDCT tedavisinden sonra Odom kriterlerine göre mükemmel olduğunu bildiren hastalarda disk hacminin azaldığı tespit edildi $(p<0.01)$.

Sonuç: Bu çalışma PDCT'nin seçilmiş SDH'li hastalar için güvenli, etkili ve minimal invaziv bir tedavi tekniği olduğunu göstermiştir.

Anahtar sözcükler: Servikal disk hernisi; disk hacmi; plazma lazer tedavi; vizüel analog skala.

\footnotetext{
'Department of Anaesthesiology and Reanimation, Firat University, Faculty of Medicine, Elazığ, Turkey 2Department of Pain Management, Ankara Training and Research Hospital, Ankara, Turkey ${ }^{3}$ Department of Radiology, Fırat University Faculty of Medicine, Elazı̆g, Turkey ${ }^{4}$ Department of Pain Management, Acıbadem Hospital, ístanbul, Turkey
}

Submitted (Başvuru tarihi) 20.07.2020 Accepted after revision (Düzeltme sonrası kabul tarihi) 08.09.2020 Available online date (Online yayımlanma tarihi) 04.03.2021

Correspondence: Dr. Sibel Özcan. Firat Üniversitesi Tip Fakültesi, Anesteziyoloji ve Reanimasyon Anabilim Dalı, Elazı̆̆, Turkey. Phone: +90 - 424 - 2333555 / 1902 e-mail: dr.sibelcozcan@gmail.com

() 2021 Turkish Society of Algology 


\section{Introduction}

Cervical radiculopathy is characterized by unilateral or bilateral arm pain with or without neck pain, often accompanied by numbness and tingling of the affected extremity, that results from mechanical compression of the cervical spinal roots. ${ }^{[1]}$ Cervical spondylosis and disc herniation are the most common causes of cervical spinal root compression. The initial treatment of cervical disc hernia $(\mathrm{CDH})$ is conservative care including analgesics and physical therapy. When conservative treatment fails, invasive treatments such as surgical procedures or epidural steroid injections are considered. ${ }^{[2,3]}$ The choice of $\mathrm{CDH}$ treatment is still controversial due to the fact that the advantages of surgical treatment methods when compared to nonsurgical ones have not yet been clearly defined. ${ }^{[4]}$ The reasons for the increasing interest in percutaneous interventions include the fact that the procedure leads to lower tissue damage and early recovery, and avoids the risks of general anesthesia since it could be performed with local anesthesia. ${ }^{[5]}$ Thus, certain percutaneous procedures have recently been developed for $\mathrm{CDH}$ treatment, including mechanical or energy-based removal of a portion of the nucleus pulposus. ${ }^{[6,7]}$

In recent years, percutaneous laser disc decompression (PLDD) has been applied frequently and was successful in $63-89 \%$ of the cases and the reported complication rate was extremely low $(0.5-1 \%) .^{[8-10]}$ Conventional laser is used in PLDD and due to conductivity and directionality of conventional laser beam, sufficient energy transfer may not be possible in the lesion region and it may lead to nerve root damages. ${ }^{[11]}$ Percutaneous plasma disc coagulation therapy (PDCT) utilizes the laser known as plasma light. In plasma light laser, the rays are concentrated at the end of the dome-shaped fiber and do not travel linearly. Thus, PDCT sends sufficient energy to the lesion site, while not damaging the surrounding soft and neural tissues. ${ }^{[12]}$ In the literature, there are only a few studies on PDCT applications. Although two studies demonstrated that PDCT application decreased the pain score in $\mathrm{CDH}$, long-term effects of PDCT on the process were not well documented. ${ }^{[13,14]}$

The main aim of the present study was to analyze the long-term effects of PDCT on pain score, disc volume, and patient satisfaction.

\section{Material and Methods}

The current study was approved by local ethics committee. Data on patients who underwent PDCT procedure for CDH in the pain clinic between May 1, 2013, and May 31, 2017, were evaluated retrospectively.

\section{Patient demographics}

From a total number of 90 patients with $\mathrm{CDH}$ who were treated with PDCT, 80 patients ( 26 males and 54 females, between 29 and 69 years old) who were able to comply with the 12-month follow-up period were included in the study. Inclusion criteria were as follows: Patients who typically experienced neck and upper limb pain. Every patient had neck pain radiating down to the hand and often to the scapular region. Nerve root compression was confirmed by computerized tomography (CT) or magnetic resonance imaging (MRI) in all patients. All participating patients failed to respond to conservative treatments or interlaminar epidural steroid injections for at least 6 weeks. Exclusion criteria included evidence of significant disc degeneration (Pfirrmann 4 and 5), the presence of sequestrated or migrated disc herniation, stenosis of intervertebral foramina or of the spinal canal, asymptomatic disc bulging incidentally diagnosed by CT or MRI, history of cervical spinal surgery or anterior neck surgery, infections, pregnancy, neoplastic disease, and hemorrhagic diathesis. All the patients provided informed consent on the day before the procedure.

\section{Plasma disc coagulation procedure}

All PDCT procedures were performed by a single physician. To prevent the risk of infection, $1 \mathrm{~g}$ cephazolin was administered intravenously (iv), $1 \mathrm{~h}$ before the procedure. Patients were monitored in the operating room and received conscious sedation with $2 \mathrm{mg}$ midazolam and $50 \mu \mathrm{g}$ fentanyl iv. The procedure was conducted with fluoroscopy with a C-arm unit, when the patients were in supine position. To facilitate access to cervical disc, a roll support was placed under the neck to facilitate neck extension. Under the guidance of anteroposterior (AP) C-arm fluoroscopy image, a target disc was determined. After sterilization of the neck, $2 \mathrm{~mL}$ lidocaine was injected into the skin and subcutaneous tissues as a local anesthetic. Since the esophagus is located on the left side of the midline, it was considered that a right-sided approach was relatively safer. Turning the patient's 


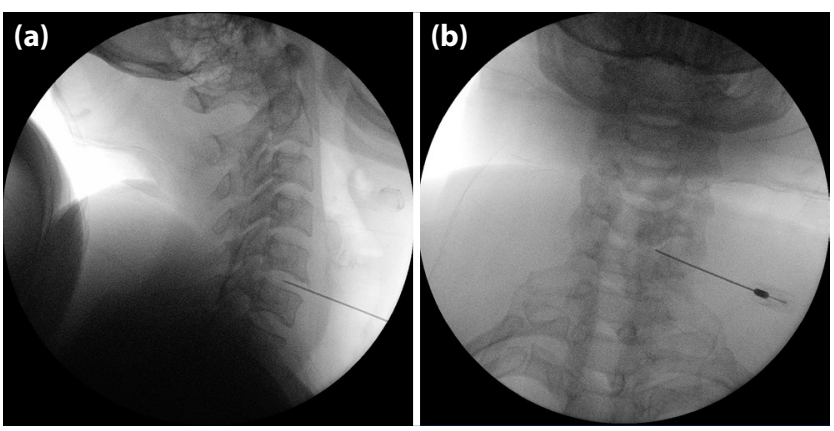

Figure 1. (a) Lateral C-arm fluoroscopic images of Chiba needle inserted in C5-C6 intradiscal space. (b) Anteroposterior C-arm fluoroscopic images of Chiba needle inserted in C5-C6 intradiscal space.

head slightly to the left may draw the esophagus and trachea to the left and out of the needle pathway. Tight pressure was applied to the safety zone between the trachea and the medial border of the sternocleidomastoid muscle to displace the carotid artery and jugular vein laterally and the trachea and larynx medially. ${ }^{[8,15]}$ The cannula $(19-$ gauge $7.5 \mathrm{~cm}$ ) was advanced toward the center of the disc. Depth of needle in the disc was confirmed by the AP and lateral C-arm fluoroscopic images (Fig. 1). After the cannula insertion to the disc, three-way valve was connected to check the ventilation of evaporated gas during the procedure. Under fluoroscopic guidance, $0.4 \mathrm{~mm}$ diameter plasma optical fiber was inserted into the intervertebral disc. Plasma light was irradiated with a total energy of 500J, as applied in the previous studies. ${ }^{[12,13]}$ We checked the patient's status and ventilation of evaporated gas by the three-way valve throughout the procedure.

In the case of hematoma, tampon pressure was planned. A possible headache due to dural injury was planned to be treated by daily fluid intake, oral caffeine or caffeine-containing painkiller, iv hydration, and epidural blood patch if the headache did not cease after 1 week of treatment.

Patients were observed for $2 \mathrm{~h}$ after the procedure and then discharged without any complications with a prescription of anti-inflammatory and analgesic drugs for 5 days. A soft cervical collar was suggested for 1 week to limit neck movement.

\section{Data collection and analysis}

Data on the age, gender, duration of pain, initial pain score obtained through visual analog scale (VAS), location of pain, and MRI findings were recorded be- fore the procedure. VAS scores were recorded by face to face interview in the $1^{\text {st }}, 3^{\text {rd }}, 6^{\text {th }}$, and $12^{\text {th }}$ months after PDCT by an anesthesia assistant. We evaluated patient satisfaction based on Odom criteria ${ }^{[16]}$ 12 months after the PDCT. Odom criteria indicate that "patients with no complaints and can perform daily activities without impairment" as excellent; "patients with intermittent discomfort related to cervical disc disease that does not significantly interfere with their work" as good; "patients with subjective improvement, whose physical activities were still significantly limited" as satisfactory; and "patients whose condition did not improve or worsened after the treatment" as poor.

The efficacy of most intradiscal procedures is tied to a particular discal volume so in this study disc volume measured 12 months after the PDCT in patients who reported excellent results based on the Odom criteria and where a reduction in disc volume was recorded. Intervertebral disc volumetric analysis was conducted manually by identification of the regions of interest (ROIs) on axial FSE-T2 MRI images. Entire disc and herniated portion were included in the ROI on all axial images slices.

\section{Statistical analysis}

The SPSS statistics software (SPSS Institute, Chicago, IL, USA), version 22.0 for Windows was used in data analysis. A number of patients were determined by power analysis, which suggested minimum of 15 individuals with an alpha error of 0.05 and a beta error of 0.10 (power $=0.90$ ). A Shapiro-Wilk test was used to verify the normal distribution of the variables.

Time-dependent effects of PDCT administration on VAS pain scores (initially and in the $1^{\text {st }}, 3^{\text {rd }}, 6^{\text {th }}$, and $12^{\text {th }}$ months after the PDCT) were evaluated with two-way repeated ANOVA followed by the Student-Newman-Keuls multiple range post hoc test. Odom criteria were compared with Yates' corrected Chi-square test. The impact of PDCT on disc volume was analyzed using the paired t-test. Statistical significance was accepted as $p<0.05$.

\section{Results}

Eighty patients were included in the present study (26 male and 54 female patients), with a mean age of 48.5 (range: 29-69). Single-level PDCT was 
Table 1. Patient demographics and plasma disc coagulation therapy application levels

\begin{tabular}{lcc}
\hline & $\begin{array}{c}\text { No. (\%) or } \\
\text { M (SD) }\end{array}$ & Min.-Max. \\
\hline Sex, female* & $54(67.5)$ & - \\
Age, y & $48.5(20)$ & $29-69$ \\
Symptom duration, w & $10.5(7.5)$ & $6-20$ \\
Location of pain* & & \\
Neck+Left arm & $26(32.5)$ & - \\
Neck+Right arm & $22(27.5)$ & - \\
Neck+Bilateral arm & $32(40)$ & - \\
MRI* & & - \\
Bulging of disc & $20(25)$ & - \\
Protruded disc & $51(63.7)$ & - \\
Extruded disc & $9(11.2)$ & - \\
PDCT application levels* & & - \\
C3-C4 & $10(12.5 \%)$ & - \\
C4-C5 & $10(12.5 \%)$ & - \\
C5-C6 & $23(28.8 \%)$ & - \\
C6-C7 & $20(25 \%)$ & - \\
C3-C4, C4-C5 & $1(1.2 \%)$ & - \\
C4-C5, C5-C6 & $6(7.5 \%)$ & - \\
C5-C6, C6-C7 & $9(11.2)$ & - \\
C4-C5, C5-C6, C6-C7 & $1(1.2 \%)$ & - \\
\hline & & - \\
\hline
\end{tabular}

SD: Standard deviation; Min.: Minimum; Max.: Maximum; MRI: Magnetic resonance imaging; PDCT: Plasma disc coagulation therapy; ${ }^{*}$ : Data presented as number of patients (\% of sample).

administered to 63 patients, while the administration was at several levels in others. Lesions were predominantly at the $\mathrm{C} 5-\mathrm{C} 6$ and $\mathrm{C} 6-\mathrm{C} 7$ distances. Patient demographics and PDCT application levels are presented in Table 1.
Clinical success of PDCT was analyzed with VAS scores. It was determined that the time-dependent VAS scores were statistically significant $(p<0.01)$, and these scores are presented in Figure $2 a$. The initial mean VAS score was $6.5 \pm 0.9(\min : 4$, max: 9$)$, and it decreased to $3.4 \pm 0.2$ (min: 0 , max: 8 ) on the final follow-up. When the patients were evaluated based on MRI pathology, VAS scores after PDCT were higher in patients with an extruded disc when compared to patients with bulging and protruded disc at all times (Fig. 2b, $p<0.05$ ).

The clinical efficacy rates were also analyzed based on patient satisfaction using Odom criteria. After 12 months, 50\% of patients reported excellent and $8.7 \%$ of patients reported poor outcomes based on the Odom criteria (Fig. 3).

MRI was obtained 12 months after the PDCT procedure for 10 out of the 40 patients who reported that they felt excellent based on the Odom criteria (Fig. 4). In these patients, initial mean disc volume was $13.6 \pm 3.5 \mathrm{~cm}^{3}$. Disc volume was decreased to $11.3 \pm 2.5 \mathrm{~cm}^{3}$ at 12 months after the PDCT and was found to be statistically significant (Fig. $5, p<0.01$ ). Five out of seven patients who were considered unsuccessful based on the Odom criteria were then scheduled for an operation. Of these five patients, two had protruded disc and three had extruded disc. There were few perioperative complications in the patients that underwent PDCT. However, vascular injury, new neurological deficits or symptoms, hoarseness, dysphagia, discitis, infection, hematoma, leakage of cerebrospinal fluid, nerve root or spinal cord

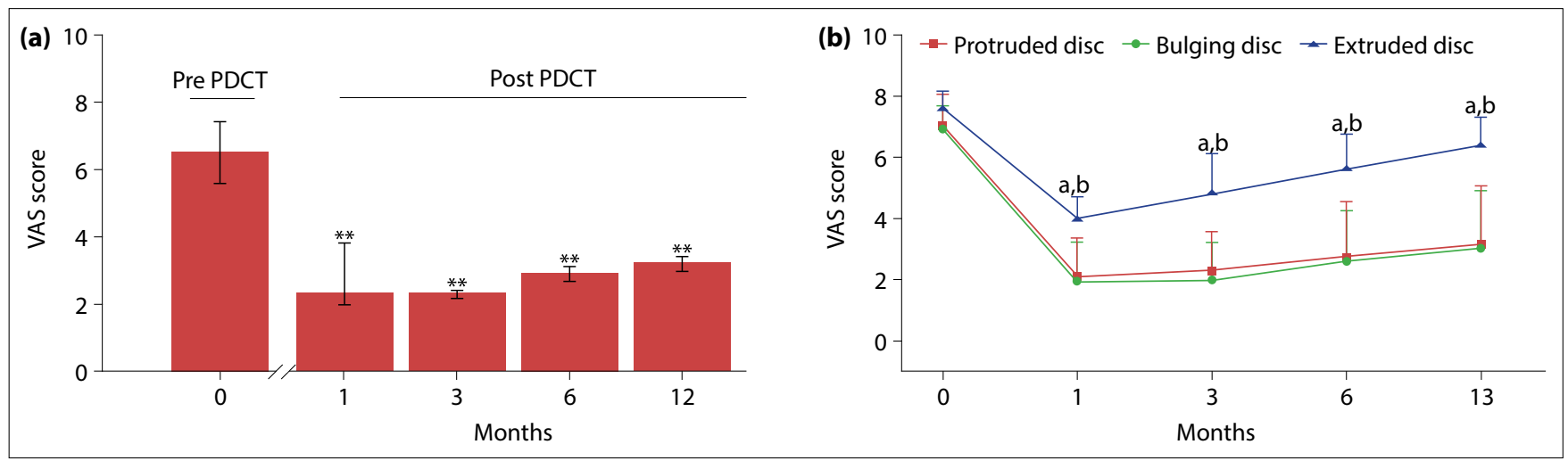

Figure 2. (a) Time-dependent effects of Plasma Disc Coagulation Therapy (PDCT) application on VAS pain score. VAS scores are recorded initially and in $1^{\text {st }}, 3^{\text {rd }}, 6^{\text {th }}$ and $12^{\text {th }}$ months after PDCT administration. Each bar represents the mean and SD for eighty patients. ${ }^{* *} \mathrm{P}<0.01$ compared with pre PDCT using the Student-Newman-Keuls (SNK) test. (b) According to MRI pathology, VAS score in $1^{\text {st }}, 3^{\text {rd }}, 6^{\text {th }}, 9^{\text {th }}$ and $12^{\text {th }}$ months after PDCT administration. The extruded disc group was compared to the protruded disc and bulging of disc groups using the Student-Newman-Keuls (SNK) test. a: $\mathrm{P}<0.05$ compared to protruded disc; $\mathrm{b}: \mathrm{P}<0.05$ compared to bulging of disc. 


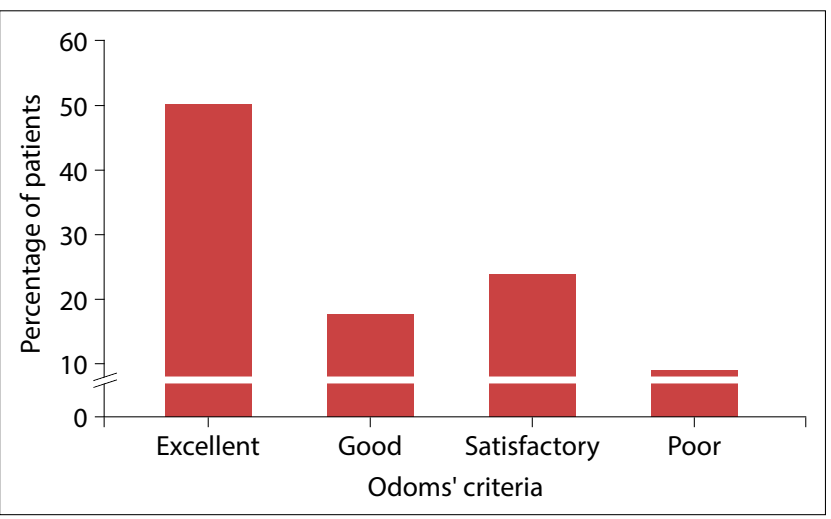

Figure 3. Effects of PDCT administration on satisfaction levels based on Odoms' criteria in patients with cervical disc hernia.

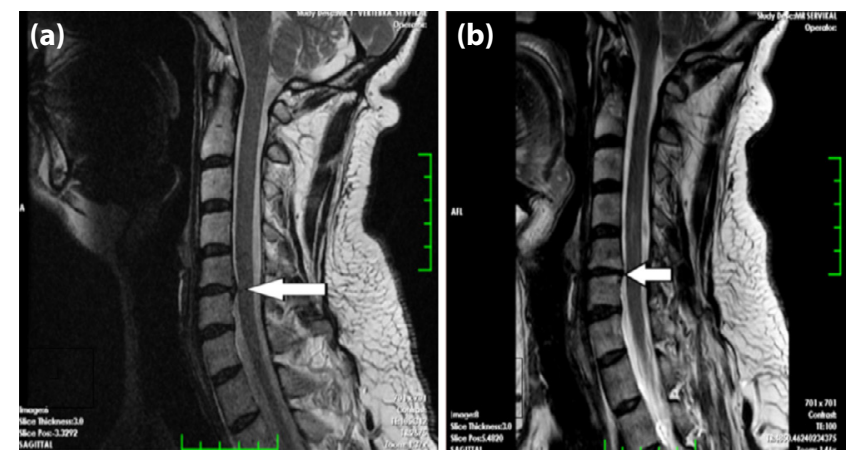

Figure 4. Magnetic resonance imaging (MRI) of spine (a) an original view of one patient's disc volume before the PDCT treatment, (b) an original view of same patient's disc volume 12 months after the PDCT treatment.

injury, and cardiovascular or pulmonary complication incidences were not observed.

\section{Discussion}

In recent years, less invasive procedures that utilize mechanical, chemical, and thermal methods to shrink the disc, in the treatment of $\mathrm{CDH}$ patients, have been developed. In the present study, we evaluated the long-term effects of PDCT in 80 patients with $\mathrm{CDH}$. During the follow-up period, a statistically significant reduction was noted in VAS scores. While the VAS score of patients before the PDCT was $6.5 \pm 0.9$, a significant decrease was obtained in VAS score 2 months after the PDCT (2.3 \pm 1.5$)$, and low VAS scores were maintained during the 12-month followup period. Analysis of the patients based on MRI pathology demonstrated that the decrease in VAS score was more significant in patients with bulging and protruded discs when compared to those with extruded discs. Odom criteria assessment revealed that PDCT was considered successful by $67.5 \%$ of the patients ( 40 excellent and, 14 good). Disc volume was measured in 10 patients who reported that they

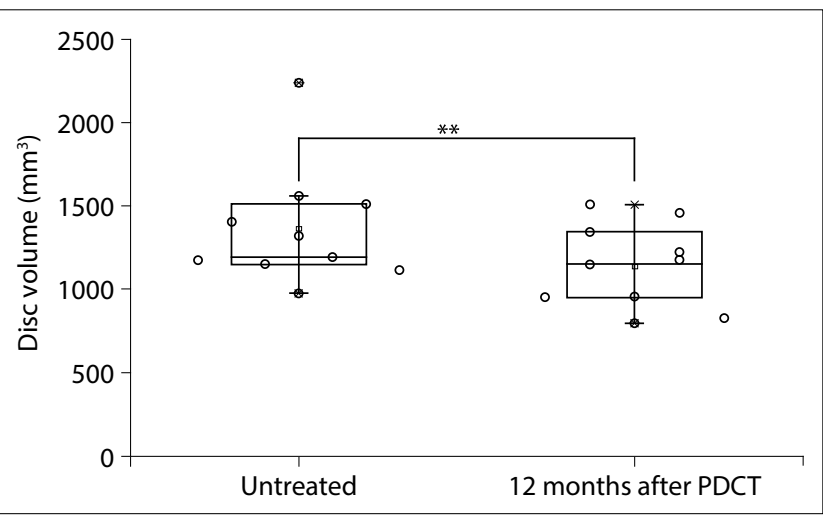

Figure 5. Effects of the PDCT treatment on intervertebral disc volume in 10 patients with cervical disc hernia. Ten patients had excellent outcomes based on the Odom's criteria.

were excellent based on the Odom criteria, and a statistically significant reduction in disc volume was determined after the PDCT procedure when compared to the pre-PDCT period.

The main objective of interventional techniques in disc herniation treatment is to reduce the internal pressure in the disc and decompress the nerve root. Ultimately, it can reduce the inflammation responsible for the pain. ${ }^{[17,18]}$ In percutaneous procedures that utilize laser, laser evaporates the fluid inside the disc and leads to a decrease in disc size. Since intervertebral disc is essentially included a hydraulic system, even a small decrease in volume would lead to a quite large reduction. This is also supported by the findings of in vitro studies. ${ }^{[19-21]}$ Laser is applied through a fiber and results in vaporization of the contents of nucleus pulposus. ${ }^{[19]}$ Its short-term effect is the vaporization of fluid inside the nucleus pulposus, and its long-term effect is the outcome of protein denaturation that increases the disc tissue tension and limits the fluid absorption capacity of the nucleus. ${ }^{[22,23]}$ There is no consensus on the most efficient or safe use or the ideal wavelength required for the procedure. Most lasers provide $1200 \mathrm{~J}$ of pulsatile energy. While there is a risk of burning the tissue in high-energy lasers, low-energy lasers may be inadequate for vaporization. In percutaneous laser discectomy, neodymium: yttrium-aluminum-garnet laser (Nd:YAG), holmium: yttrium-aluminum-garnet laser (Ho:YAG), and diode laser are used. In percutaneous laser discectomy, linear beam which may accumulate and lead to damages in anterior longitudinal ligament, nerve root, and end plates by penetrating into disc anterior is used. However, it may not provide sufficient energy for the disc itself. ${ }^{[22-24]}$ 
PDCT was developed in 2006 to correct and improve the linear spread property. The PDCT system is a percutaneous treatment method that uses plasma light (within the range of $550-1800 \mathrm{~nm}$ ) for disc coagulation and decompression. In the PDCT system, plasma light is condensed at the tip of a dome shaped fiber with a temperature between $160^{\circ} \mathrm{C}$ and $164^{\circ} \mathrm{C}$ and $<40^{\circ} \mathrm{C}$ at over $3 \mathrm{~mm}$ around the fiber, thus, the healthy tissues are protected from thermal elevations, allowing the operator to produce thermal damage only on a specific region. ${ }^{[12,25]}$ As a result of the optimized cavity occurring in disc, internal pressure is reduced and the pressure of nucleus pulposus on the nerve is decreased..$^{[12,24]}$

The outcome of percutaneous disc coagulation therapy was compared to that of the automatic percutaneous lumbar discectomy, and it was demonstrated that percutaneous disc coagulation therapy was more efficient when compared to the automated percutaneous lumbar discectomy (APLD) (80\% favorable outcome in PDCT and 64\% in APLD). ${ }^{[26]}$ Kim et al. ${ }^{[12]}$ reported that PDCT treatment in patients with herniated lumbar disc led to a decrease in VAS score and in $89.1 \%$ of patients had achieved favorable improvement.

In the literature review, we found only a few articles on the use of PDCT in patients with cervical disc herniation. Zini et al. ${ }^{[13]}$ reported the findings on 54 patients with lumbar or cervical disc herniation (48 lumbar and 6 cervical) treated with PDCT after 4 months. They reported that all patients well tolerated the procedure, there was a significant decrease in the VAS and Oswestry Disability Index scores after the PDCT, and no serious complications were observed. However, the sample size in that study was very small and the follow-up period was too short to argue that PDCT was successful in $\mathrm{CDH}$ treatment.

In another study, the efficacy of PDCT was compared to a navigable ablation decompression treatment ( $\mathrm{L}-$ DISQ) in CDH treatment. The authors reported that L-DISQ provided better pain control when compared to PDCT during the early period, however, both techniques had a similar impact in the long term. They followed up the patients for 12 months and reported that the decrease in VAS and NPI scores was statistically significant, and L-DISQ treatment provided better pain control when compared to PDCT during the early period, however, the long-term effects were similar. They reported no serious complications in the study. ${ }^{[14]}$

Similar to these findings, we found that PDCT was effective in the treatment of patients with $\mathrm{CDH}$. In the literature review, no analysis was conducted based on MRI findings. When the patients were classified based on the MRI findings in the present study, it was found that PDCT was more effective in patients with bulging and protruded discs. Usually, bulging of the disc responds to conservative treatments, however, the patients in our study group were resistant to conservative treatment for a long time. It is also known that clinical findings do not always correlate with the patient's MRI findings. Therefore, PDCT procedure was conducted in the group of patients with bulging discs. On the other hand, although surgery is recommended as the general treatment in extruded disc herniation, the patients in our study group did not accept surgical advice. Despite PDCT provided adequate pain control and this effect continued for 12 months, $67.5 \%$ of the patients reported favorable outcome based on the Odom criteria. To demonstrate the efficacy of PDCT treatment, disc volume was measured in 10 patients with excellent results and a statistically significant reduction in disc volume was determined after the PDCT.

There were no serious complications during and after the procedure. Approach from the safety zone that was described in the previous studies prevented the possible complications. ${ }^{[8,15]}$

However, the present study had several limitations. First, the lack of a control group was a disadvantage. Second, this was a retrospective study, and our aim was to evaluate our results in comparison with the results of the previous studies. Another limitation was that psychological state, functional capacity, and quality of life were not evaluated in the present study.

\section{Conclusions}

The findings of the present clinical study demonstrated that PDCT is a safe, effective, and minimally invasive treatment technique for adequately selected patients, especially for those with bulging and protrusion in cervical discs and refractory to conservative treatment. 
Ethics Committee Approval: The current study was approved by local ethics committee. Data on patients who underwent PDCT procedure for CDH in the pain clinic between May 1, 2013, and May 31, 2017, were evaluated retrospectively.

\section{Conflict-of-interest issues regarding the authorship or article: None declared.}

\section{Peer-rewiew: Externally peer-reviewed.}

\section{References}

1. Corniola MV, Tessitore E, Schaller K, Gautschi OP. Cervical disc herniation-diagnosis and treatment. Rev Med Suisse 2015;11(492):2023-9. [CrossRef]

2. Kloth DS, Calodney AK, Derby R, Lagattuta FP, O'Neill C, Yurth $E$, et al. Improving the safety of transforaminal epidural steroid injections in the treatment of cervical radiculopathy. Pain Physician 2011;14(3):285-93. [CrossRef]

3. Mansfield M, Smith T, Spahr N, Thacker M. Cervical spine radiculopathy epidemiology: A systematic review. Musculoskeletal Care 2020;18(4):555-67. [CrossRef]

4. Gebremariam L, Koes BW, Peul WC, Huisstede BM. Evaluation of treatment effectiveness for the herniated cervical disc: A systematic review. Spine (Phila Pa 1976) 2012;37(2):109-18. [CrossRef]

5. Nasser R, Yadla S, Maltenfort MG, Harrop JS, Anderson DG, Vaccaro $A R$, et al. Complications in spine surgery. J Neurosurg Spine 2010;13(2):144-57. [CrossRef]

6. Harada J, Dohi M, Fukuda K, Nakazaki H, Koyama T, Abe T. CTguided percutaneous laser disk decompression (PLDD) for cervical disk hernia. Radiat Med 2001;19(5):263-6.

7. Romero-Rangel JA, Soriano-Solís S, Rodríguez-García M, Soto-García ME, Soriano-Solís H, Aranda-Torres BY, et al. Dysphagia rates after minimally invasive tubular approach to the anterior cervical spine. Cir Cir 2020;88(3):286-91.

8. Kelekis AD, Filippiadis DK, Martin JB, Brountzos E. Standards of practice: Quality assurance guidelines for percutaneous treatments of intervertebral discs. Cardiovasc Intervent Radiol 2010;33(5):909-13. [CrossRef]

9. Alo KM, Wright RE, Sutcliffe J, Brandt SA. Percutaneous lumbar discectomy: One-year follow-up in an initial cohort of fifty consecutive patients with chronic radicular pain. Pain Pract 2005;5(2):116-24. [CrossRef]

10. Filippiadis DK, Kelekis A. A review of percutaneous techniques for low back pain and neuralgia: Current trends in epidural infiltrations, intervertebral disk and facet joint therapies. Br J Radiol 2016;89(1057):20150357. [CrossRef]

11. Zhao XL, Fu ZJ, Xu YG, Zhao XJ, Song WG, Zheng H. Treatment of lumbar intervertebral disc herniation using $\mathrm{C}$-arm fluoroscopy guided target percutaneous laser disc decompression. Photomed Laser Surg 2012;30(2):92-5. [CrossRef]

12. Kim SH, Kim SC, Cho KH. Clinical outcomes of percutane- ous plasma disc coagulation therapy for lumbar herniated disc diseases. J Korean Neurosurg Soc 2012;51(1):8-13.

13. Zini C, Notaro D, Sadotti G, Zini G, Monti L, Bellini M. Percutaneous intervertebral disc coagulation therapy (PDCT) by plasma light: Preliminary data from the first experience in Europe. Cardiovasc Intervent Radiol 2020;43(1):94-102.

14. Ceylan A, Aşık I. Percutaneous plasma laser disc coagulation and navigable ablation decompression in the treatment of cervical disc herniation: A single center experience. Turk J Med Sci 2019;49(1):258-64. [CrossRef]

15. Lee $\mathrm{SH}$, Kim KT, Jeong BO, Seo EM, Suk KS, Lee JH, et al. The safety zone of percutaneous cervical approach: A dynamic computed tomographic study. Spine (Phila Pa 1976) 2007;32(20):569-74. [CrossRef]

16. Odom GL, Finney W, Woodhall B. Cervical disk lesions. J Am Med Assoc 1958;166(1):23-8. [CrossRef]

17. Kelekis A, Filippiadis DK. Percutaneous treatment of cervical and lumbar herniated disc. Eur J Radiol 2015;84(5):771-6.

18. Freemont AJ. The cellular pathobiology of the degenerate intervertebral disc and discogenic back pain. Rheumatology (Oxford) 2009;48(1):5-10. [CrossRef]

19. Belykh E, Yagmurlu K, Martirosyan NL, Lei T, Izadyyazdanabadi $M$, Malik KM, et al. Laser application in neurosurgery. Surg Neurol Int 2017;8:274. [CrossRef]

20. Plapler H, Mancini MW, Sella VR, Bomfim FR. Evaluation of different laser wavelengths on ablation lesion and residual thermal injury in intervertebral discs of the lumbar spine. Lasers Med Sci 2016;31(3):421-8. [CrossRef]

21. Schenk B, Brouwer PA, Peul WC, van Buchem MA. Percutaneous laser disk decompression: A review of literature. AJNR Am J Neuroradiol 2006;27(1):232-5.

22. Ren L, Guo B, Zhang T, Bai Q, Wang XH, Zhang L, et al. Medium-term follow-up findings in imaging manifestation after percutaneous laser disc decompression. Photomed Laser Surg 2013;31(6):247-51. [CrossRef]

23. Radcliff K, Vaccaro AR, Hilibrand A, Schroeder GD. Lasers in spine surgery. J Am Acad Orthop Surg 2019;27(17):621-32.

24. Tassi GP. Comparison of results of 500 microdiscectomies and 500 percutaneous laser disc decompression procedures for lumbar disc herniation. Photomed Laser Surg 2006;24(6):694-7. [CrossRef]

25. Gerszten PC, Smuck M, Rathmell JP, Simopoulos TT, Bhagia SM, Mocek CK, et al. Plasma disc decompression compared with fluoroscopy-guided transforaminal epidural steroid injections for symptomatic contained lumbar disc herniation: A prospective, randomized, controlled trial. J Neurosurg Spine 2015;12(4):357-71. [CrossRef]

26. Park CW, Lee JY, Choi WJ, Chang SK. Percutaneous disc coagulation therapy (PDCT) comparing with automated percutaneous lumbar discectomy (APLD) in patients of herniated lumbar disc disease: Preliminary report. Korean J Spine 2012;9(3):159-64. [CrossRef] 